論 文

\title{
水中音響通信のための差動多重シングルキャリア伝送方式と そのフィールド試験結果
}

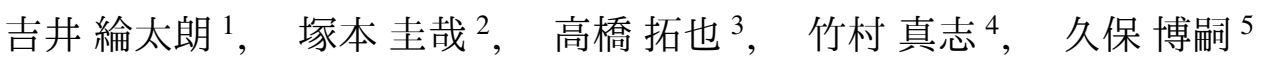

$1,2,3,4$ 立命館大学院 理工学研究科, $\bar{T} 525-8577$ 滋賀県 草津市 野路東 1-1-1

5 立命館大学 理工学部 電子情報工学科, ₹ 525-8577 滋賀県 草津市 野路東 1-1-1

\section{Differential Multiple Single Carrier Modulation Schemes for Underwater Acoustic Communications and These Experimental and Field Evaluation Results}

\author{
Rintaro Yoshii ${ }^{1}$, Yoshiki Tsukamoto ${ }^{2}$, Takuya Takahashi ${ }^{3}$, Masashi Takemura ${ }^{4}$ and Hiroshi Kubo ${ }^{5}$ \\ 1, 2, 3, ${ }^{4}$ Graduate School of Science and Engineering, Ritsumeikan University \\ 1-1-1 Noji-Higashi, Kusatsu-shi, Shiga 525-8577, Japan \\ ${ }^{5}$ Department of Electronic and Computer Engineering, Faculty of Science and Engineering, Ritsumeikan University \\ 1-1-1 Noji-Higashi, Kusatsu-shi, Shiga 525-8577, Japan \\ E-mail: $\left\{{ }^{1}\right.$ ri0055hp, ${ }^{2}$ ri0051vf, ${ }^{3}$ ri0051se\}@ed.ritsumei.ac.jp, ${ }^{5}$ kubohiro@fc.ritsumei.ac.jp
}

\begin{abstract}
This paper discusses experimental and field evaluation results of differential multiple single carrier (MSC) modulation schemes for underwater acoustic communications (UWACs). UWACs suffer from severe doubly-selective channels and inter-carrier interference due to non-uniform frequency offset. In addition, assuming image data communications, UWACs have to improve frequency efficiency. In order to solve these issues, this paper proposes a wireless transmission scheme, which employ differential MSC modulation schemes. Next, this paper investigates parameters for 8kbps-UWACs and 64kbps-UWACs aiming at wireless control of autonomous underwater vehicle and image data communications, respectively. Finally, two experimental and field evaluation results in acoustic experimental pool and shallow-sea environment confirm that the UWAC MODEMs have excellent performance on severe doubly-selective channels.
\end{abstract}

Keywords: underwater acoustic communication, channel prediction, doubly-selective channel, per-survivor processing, multi-carrier modulation scheme, multi-level modulation

\section{1. まえがき}

近年，海洋資源開発への関心が高く，海洋探索に おいて重要な役割を果たす水中無線技術への関心が 高まっている [1]。水中無線技術の応用範囲は, AUV (autonomous underwater vehicle) の無線制御，画像デー 夕通信等への適用が期待されている $[2]$ 。水中では電
波と比較して，減衰が少ない音波を通信媒体として 用いることが多く，水中音響通信 (UWAC : underwater acoustic communications) として様々な研究が行われて いる[1]-[6]。しかし，伝送媒体が電波から音波へと変 わることで問題が発生する。水中音響通信の主な課題 は以下 3 点である。

・厳しい 2 重選択性伝搬環境への対応 
・不均一なキャリア間干渉 (ICI : inter carrier interference) への対応

- 周波数利用効率の改善

1つ目の課題の周波数選択性に対しては, キャリアを 並列伝送する，マルチキャリア (MC : multi carrier) 伝 送方式が有効である [7]。しかし，MC 伝送方式によ り各サブキャリアの占有帯域幅を減少させると, 伝送 路変動の影響が増大する。高速に変動する伝送路に対 しては, 遅延検波 (DD : differential detection) が有効で ある [8]。しかし，MC 伝送方式を前提とした場合, シ ンボル周期が拡大するため, さらに優れた耐伝送路変 動特性を有する通信方式が必要である。2つ目の課題, 不均一な ICI に対して, 各サブキャリアに対して補正 が可能なため, シングルキャリアを並列伝送する多重 シングルキャリア (MSC: multiple single carrier) 伝送方 式が有効である。3つ目の課題, 伝送効率の改善を考 えた時, MIMO (multiple-input multiple-output) [6]や OFDM (orthogonal frequency-division multiplexing) [4], [5], 変調多值化が考えられる。以上より, UWACでは $\mathrm{MC}$ 伝送方式を前提として, 優れた耐伝送路変動特性 を有する通信方式を用いることが有効と考えられる。 画像データ通信を考える場合は, 加えて高い周波数利 用効率を有する通信方式が有効である。

DD を拡張した方式の一つとして多重遅延検波 (MDD: multiple differential detection) がある [9]。MDD は DD と比較して静特性が優れている特徵を持つ。ま た，MDD は伝送路予測を適用することで伝送路変動 に対する追随性の改善が可能である。特に伝送路予測 を用いた PSP-MDD (MDD based on per-survivor processing) [10] は優れた耐伝送路変動特性を有しており， 高速時変伝送路への追随特性を伝送路予測次数により 制御できる特徵を持つ。さらに, 伝送路予測を適応し た PSP-MDD は変調多值数を増加させた場合でも, DD と比較して良好な耐伝送路変動特性を持つ [11]。本論 文では，UWAC のような厳しい 2 重選択性伝搬環境 について検討する。

著者らは, 文献 [12]について, UWAC のような厳し い 2 重選択性伝搬環境に有効な伝送路予測 PSP-MDD と差動 MSC 伝送方式を用いた UWAC モデムについ て論じているが，伝送速度は $8 \mathrm{kbps}$ に限定しており， また，実際の海洋浅瀬環境の性能も明らかになってい ない。

本論文では UWAC モデムとして，AUV の無線制御 用 $8 \mathrm{kbps}$ ，画像データ通信用 $64 \mathrm{kbps}$ を実現する伝送方 式を提案し，実験性能評価によりその有効性を明らか にする。実験性能評価については，実験水槽を用いた
実験により 2 重選択性伝搬環境における追随性の評価 を行う。また, 海洋浅瀬環境における準固定環境試験 を行い, 準固定環境における周波数選択性への耐性を 評価する。実験水槽を用いた試験より以下の項目 (1) を, 海洋浅瀬環境試験により以下の項目 (2), (3) を確 認する。

（1） 2 重選択性の厳しい環境では, 1 次伝送路予測を 用いた検討方式が最も良好な性能を保有する

(2) 海洋浅瀬環境での距離 $370 \mathrm{~m}$ の準固定環境試験 において, QPSK (quadrature phase shift keying) は良好な性能を示す

(3) 海洋浅瀬環境での距離 $10 \mathrm{~m}$ 程度の準固定環境試 験において，16PSK (16 phase shift keying) は良 好な性能を示す

本論文は，次の様に構成される。まず，2.では， UWAC において想定される 2 重選択性伝搬環境の厳し さについて論じ, 3.では, 厳しい 2 重選択性伝搬環境 に有効な通信方式について論じる。次に，4.では，復 調方式として用いる PSP-MDDについて述べ，5.では， 実験性能評価を行う UWAC モデムについて, フレー ム構成, また伝送方式のパラメータを示す。最後に, 6. 及び 7.では実験性能評価結果についてまとめる。

\section{2 重選択性伝搬環境}

\subsection{2 重選択性の厳しさを評価するパラメータ}

伝搬環境から無線伝送の性能に影響を及ぼす要素と して遅延波, 伝送路変動の 2 つが挙げられる。移動体 通信において，遅延波による影響は周波数選択性に関 係するシンボル周期正規化最大遅延時間差 $\tau_{D} / T$, 伝 送路変動による影響は時間選択性に関係するシンボル レート正規化最大ドップラー周波数 $f_{D} T$ を評価のパラ メータとして用いることが多い。これらパラメータに ついては次の通りである。

$$
\begin{gathered}
\tau_{D} / T=\frac{d}{c T} \\
f_{D} T=\frac{v f_{c}}{c} T
\end{gathered}
$$

ここで, $v$ は移動速度， $d$ は最大伝搬距離差， $f_{c}$ は搬 送波周波数, $c$ は電波伝搬ならば光速, 音波伝搬なら ば音速である。2 重選択性伝搬環境では 2 つ選択性 が同時に無線伝送の性能に影響を及ぼす。

MC 伝送方式の場合, 式 (1), 式 (2) はシンボル周期 $T$ をパラメータとしたトレードオフの関係であること 
が確認できる。そこで, 次の通り，2 重選択性伝搬環 境について別々に評価を行うのではなく，1つのパラ メータ $f_{D} \tau_{D}$ として 2 重選択性の厳しさを評価するこ とが可能である [13]。 $f_{D} \tau_{D}$ について, 式 (1), 式 (2) を式 (3) に代入することで，式 (4) が導出できる。

$$
\begin{gathered}
f_{D} \tau_{D}=\left(f_{D} T\right) \times\left(\tau_{D} / T\right) \\
f_{D} \tau_{D}=\frac{v d f_{c}}{c^{2}}
\end{gathered}
$$

以上より，2 重選択性伝搬環境において MC 伝送方式 を考えた場合, 環境の厳しさは $f_{D} \tau_{D}$ を算出すること で求めることが可能である。水中音響通信は, 式 (4) についてパラメータ $c$ が光速から水中における音速と 変わるため, 非常に厳しい 2 重選択性伝搬環境となる。

\section{2 各種通信システムのパラメータ比較}

本節では 2 重選択性伝搬環境の評価について, UWAC のパラメータと現在運用されているシステムのパラ メータとの比較を行う。今回は現在運用されているシ ステムの中で厳しい 2 重選択性伝搬環境といわれて いる空間波列車無線を比較対象として考える。表 1 に UWAC と空間波列車無線が想定する 2 重選択性のパ ラメータを示す。

表 12 重選択性伝搬環境を想定している通信システ ムのパラメータ

Table 1 Parameters in doubly-selective environments

\begin{tabular}{|c|c|c|}
\hline 項目 & 水中音響通信の 1 例 & 空間波列車無線 \\
\hline$d$ & $3 \mathrm{~m}$ & $10 \mathrm{~km}$ \\
\hline \multirow{2}{*}{$v$} & $3 \mathrm{knot}$ & $150 \mathrm{~km} / \mathrm{h}$ \\
& $\simeq 1.54 \mathrm{~m} / \mathrm{s}$ & $\simeq 41.7 \mathrm{~m} / \mathrm{s}$ \\
\hline$f_{c}$ & $30 \mathrm{kHz}$ & $400 \mathrm{MHz}$ \\
\hline$\tau_{D}$ & $2 \mathrm{~ms}$ & $33.3 \mu \mathrm{s}$ \\
\hline$f_{D}$ & $30.8 \mathrm{~Hz}$ & $55.6 \mathrm{~Hz}$ \\
\hline$f_{D} \tau_{D}$ & $6.16 \%$ & $0.185 \%$ \\
\hline
\end{tabular}

それぞれの通信システムの $f_{D} \tau_{D}$ について，表 1 よ り確認する。空間波列車無線の場合は $f_{D} \tau_{D}$ が $1 \%$ 未 満, UWAC の場合は数\%を越える值となることが確 認できる。このことから UWAC は極めて厳しい 2 重選 択性伝搬環境であることがわかる。以上より, UWAC では radio frequency 帯で用いられる通信システムより も高い 2 重選択性而性が要求される。

\section{2 重選択性伝搬環境のための無線伝送方式}

\subsection{MC 伝送方式}

2 重選択性伝搬環境である UWACでは, 周波数選択 性によりキャリア信号に歪を起こす。よって, UWAC では伝送速度を保ち, さらに周波数選択性耐性を向上 させる MC 伝送方式が有効である。 MC 伝送方式では シンボル周期 $T$ を決定することで, $f_{D} \tau_{D}$ を用いて対 応すべき $f_{D} T, \tau_{D} / T$ が一意的に決定する。

よく用いられる MC 伝送方式として OFDM がある。 また, OFDM とは異なる MC 伝送方式としてシング ルキャリアを並列伝送する MSC 伝送方式 [7] がある。 2 つの MC 伝送方式について, 周波数利用効率を考え る。周波数軸では MSC 伝送方式がガード周波数を, 時 間軸では OFDM がガード時間を用意する必要がある。 ガード周波数，またはガード時間を用意する場合，用 意する軸の周波数利用率は低下する。そのため, 周波 数軸と時間軸を総合的に考えた場合, OFDM と MSC 伝送方式の周波数利用効率に大きな差はないといえる。

次に, OFDM と MSC 伝送方式の信号形状を比較し てみる。OFDM の信号形状は, 時間軸上は矩形波, 周 波数軸上は sinc 関数となる。他方, ロールオフ率が 0 の MSC 伝送方式の信号形状は, 時間軸上は sinc 関 数, 周波数軸上は矩形波となる。すなわち, OFDM と MSC 伝送方式は対照的な MC 伝送方式とみなすこと ができる。なお, MSC 伝送方式がタイミング誤差に 伴う符号間干渉 (ISI : intersymbol interference) に弱い 反面, OFDM はキャリア周波数偏差に伴う ICI に対し て弱い。

\section{2 伝送路予測 joint detection}

$\mathrm{MC}$ 伝送方式について, $f_{D} \tau_{D}$ が比較的小さい領域で は, 伝送効率に優れており, パイロットにて伝送路推 定を行う同期検波 OFDM が有効である。しかし, 文献 [14] より，UWAC のような数\%を超える $f_{D} \tau_{D}$ の場合 では, 同期 OFDM は多くのシンボルをパイロットと しなければ伝送路推定が困難になる。よって, UWAC では同期検波 OFDM とは異なる伝送方式を検討する 必要がある。

$f_{D} \tau_{D}$ が数\%以上の伝搬環境では, パイロット伝送 路推定とデータ判定を同時に実施可能である JD (joint detection) が有効である。JDの典型的な例として差動 符号化/DD があり, DD を拡張した MDD も JD であ る。差動符号化を一般化したものが差動時空符号化 
(DSTC : differential space-time coding) であり, DSTC の復調方式として, decision-feedback detection と PSP が検討されている [15]。MDDについて，ビタビアル ゴリズム (VA : Viterbi algorithm)による PSP に基づ くMDD，PSP-MDDに対して伝送路予測を用いるこ とで, 伝送路変動に対する追随性を向上させることが 可能である [13]。以上より，本論文では UWAC のよ うな $f_{D} \tau_{D}$ が数\%以上の伝搬環境に有効な復調方式と して, 伝送路予測 PSP-MDD を検討する。

\section{3 差動 MSC 伝送方式}

本論文では, MC 伝送方式の中でも差動 MSC 伝送 方式を検討する [7]。その理由は UWAC が占有帯域幅 と中心周波数の除算で求められる比帯域が非常に大き い環境であり, 差動 MSC 伝送方式は, 差動 OFDMに 比べ ICI の問題が少ないためである。比帯域が大きい 場合, 占有帯域の上端と下端で受けるドップラー変動 が数倍程度異なることが問題になる。MSC 伝送方式 は各サブキャリアについて，ドップラーシフトへの補 正が可能であるため，UWAC に対する適正が高い。以 上より，本論文では UWAC に有効な通信方式として 伝送路予測 PSP-MDD を用いた差動 MSC 伝送方式を 提案する。

\section{PSP による多重遅延検波}

\section{1 検討する PSP-MDD}

本論文で検討する PSP-MDD はVA に基づき，デー タ判定を行う。VA の枝メトリック $\Gamma_{k}$ 及びパスメト リック $H$ は $N_{R}$ 系統の受信信号 $r_{k}[q]$ を用いて, 次の ように表現できる。

$$
\begin{gathered}
\Gamma_{k}=\sum_{q=1}^{N_{R}}\left|r_{k}[q]-\tilde{r}_{k}[q]\right|^{2} \\
H=\sum_{k} \Gamma_{k}
\end{gathered}
$$

ここで，PSP-MDD は，全ての情報系列の候補 $\tilde{b}_{k}$ に 対してパスメトリック $H$ を算出し, 最小のパスメト リックに対応する $\tilde{b}_{k}$ を, 判定系列 $\hat{b}_{k}$ として出力する。 以降，本論文では，信号 $a_{k}$ に関して $\tilde{b}_{k}$ に対応して推 定した信号の候補值を $\tilde{a}_{k}$ と記載する。式 (5) の $\tilde{r_{k}}[q]$ は受信信号の候補值を示す。伝送路メモリ長を 1 タッ プと設定した場合， $\tilde{r}_{k}[q]$ は推定 CIR (channel impulse response) $\tilde{h}_{k}[q]$ と送信変調信号の候補 $\tilde{x}_{k}$ を用いて次の
ように表現できる。

$$
\tilde{r}_{k}[q]=\tilde{h}_{k}[q] \tilde{x}_{k}
$$

ここで, PSP-MDD において, 推定 CIR $\tilde{h}_{k}[q]$ は受信信 号 $r_{k}[q]$ の逆変調信号 $\widetilde{G}_{k}[q]$ を用いて次のように表現 できる。

$$
\begin{gathered}
\tilde{h}_{k}[q]=\sum_{i=1}^{N} b_{i} \widetilde{G}_{k-i}[q] \\
\widetilde{G}_{k}[q]=r_{k}[q] \tilde{x}_{k}^{*}
\end{gathered}
$$

式 (8)について, $N$ は観測シンボル数, つまりビタビ アルゴリズムにおける拘束長を示しており, 係数 $b_{i}$ は 逆変調信号 $\widetilde{G}_{k}[q]$ の重み付け係数である。

$b_{i}$ について, 静特性の改善のために, 次の様に設計 する。

$$
b_{i}=1 / N
$$

式 (10) を用いた PSP-MDD は, 過去 $N$ シンボルに渡 る伝送路状態の平均化を行っている。本論文では, 式 (10) を用いた PSP-MDD の伝送路予測次数 $L$ につい て, $L=0$ と表現する。次に $b_{i}$ について伝送路変動に 対する追随性を改善するために, 文献 [10]にて, 次の ような式が提案されている。

$$
b_{i}=(-1)^{i-1}\left(\begin{array}{c}
N \\
i
\end{array}\right)
$$

ここで, 式(11)を用いた PSP-MDD の伝送路予測次数 は, 観測シンボル数に依存しており, $L=N-1$ と表 現する。

\section{2 状態数削減アルゴリズム}

4.1 記載の PSP-MDD は, PSP-MLSE (maximum-likelihood sequence estimation) と等価である。PSP-MLSE を実現するためには，VAの状態数を $M^{N-1}$ と設定す る必要がある。ここで, $M$ は変調多值数を示す。こ のことから, VA の状態数は $N$ のべき乗で増加する という問題が発生する。この問題に対応するために, 判定帰還系列推定 (DFSE : decision-feedback sequence estimation)を用いる [16]。DFSE は, VA の生き残りパ スを参照することで, 状態数を削減する。生き残りパ スを参照するシンボル数を $\Delta V$ とした場合, VA の状 態数は $M^{N-1-\Delta V}$ となる。PSP-DFSEについて, $\Delta V=0$ と設定した場合，PSP-MLSE となる。 


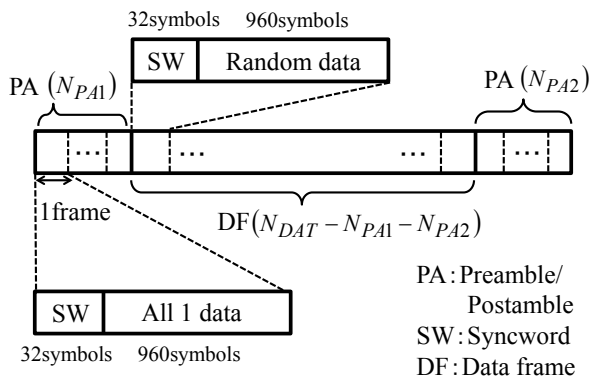

図 1 フレームフォーマット

Fig. 1 Frame format

表 2 検討する伝送方式のパラメータ

Table 2 Parameters of transmission schemes

\begin{tabular}{|c|c|c|}
\hline 伝送方式 & QPSK & 16PSK \\
\hline$\alpha$ & \multicolumn{2}{|c|}{0.2} \\
\hline$f_{s c}$ & \multicolumn{2}{|c|}{$93.75 \mathrm{sps}$} \\
\hline$M_{s c}$ & 64 & 256 \\
\hline$f_{c}$ & $30 \mathrm{kHz}$ & $28 \mathrm{kHz}$ \\
\hline Reed Solomon 符号 & $(240,166)$ & $(255,177)$ \\
\hline 略称 & DMSC2 & DMSC4 \\
\hline
\end{tabular}

\section{5. 評価する UWAC モデム}

5.1 フレームフォーマット

本節では，実験性能評価を行う際のフレームフォー マットについて述べる。送信信号のフレームフォーマッ トを図 1 に示す。図 1 について, 1 フレームを 32 シン ボルの同期語 (SW : syncword) と 960 シンボルのデー タ，合わせて 992 シンボルで構成し，全体で $N_{D A T}$ 個 のフレームを作成する。 $N_{D A T}$ 個のフレームの内，先 頭の $N_{P A 1}$ 個のフレームをプリアンブル，末尾の $N_{P A 2}$ 個のフレームをポストアンブルとする。同期について, 有限個の受信信号から SW を検出する。その後既知で ある送信情報と復調結果を照合することにより誤りを 検出し，その検出結果から BER (bit error rate) を算出 する。最後に RS (Reed Solomon) 符号による誤り訂正 により BLER (block error rate) を算出する。

\section{2 水中音響通信方式}

本節では，実験性能評価を行う PSP-MDDを用いた 差動 MSC 伝送方式について，検討する伝送方式のパ ラメータを表 2 に示す。ここで， $\alpha$ はルート余弦ロー
ルオフフィルタのロールオフ率, $f_{s c}$ はサブキャリア当 たりの伝送速度， $M_{s c}$ はサブキャリア数， $f_{c}$ は中心周 波数である。また, RS 符号の記載は, $1 \mathrm{RS}$ シンボルを 8bit として, (符号語シンボル数, 情報シンボル数) と 示す。表 2 における各伝送方式について, DMSC2 は AUV の無線制御が可能な $8 \mathrm{kbps}$, DMSC4 は画像デー タ通信が可能な $64 \mathrm{kbps}$ を想定している。

\section{6. 実験水槽試験}

本章では，2 重選択性の中でも時間選択性に重点をお いて評価を実施する。その結果，時間選択性に対して は， 1 次伝送路予測が有効であることを明らかにする。

\section{1 実験水槽試験概要}

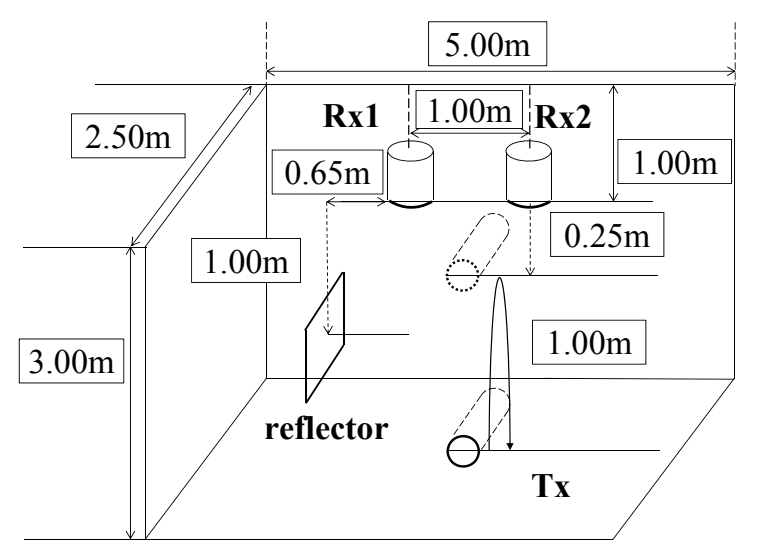

図 2 実験水槽における実験の概要図

Fig. 2 Configuration of the experiment in acoustic experimental pool

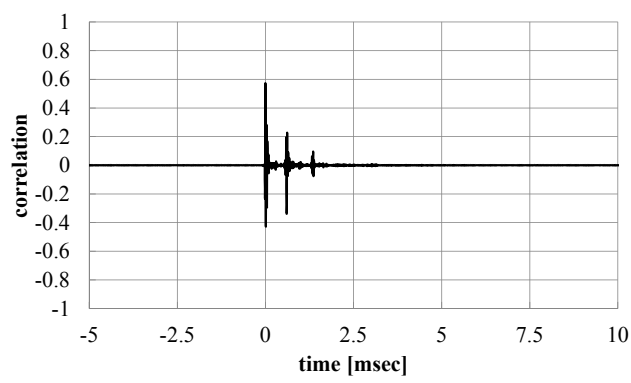

図 3 実験水槽における $\mathrm{Tx}-\mathrm{Rx} 1$ 間の CIR 特性（Tx の深度 $2.25 \mathrm{~m}$ )

Fig. 3 CIR (Tx-Rx1) in acoustic experimental pool (depth of Tx $2.25 \mathrm{~m}$ ) 


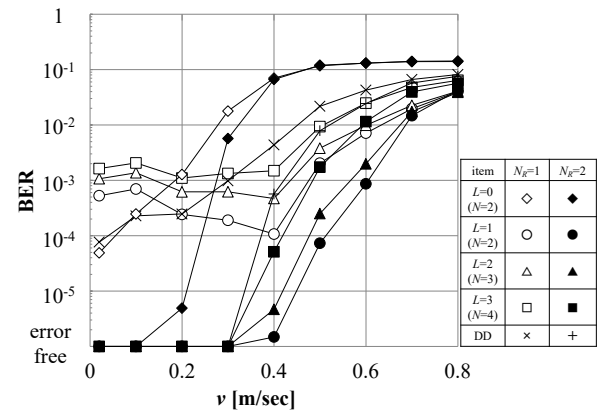

図 $4 v$ 変化時の BER 特性 (DMSC2)

Fig. 4 BER performance as a fuction of $v$ (DMSC2)

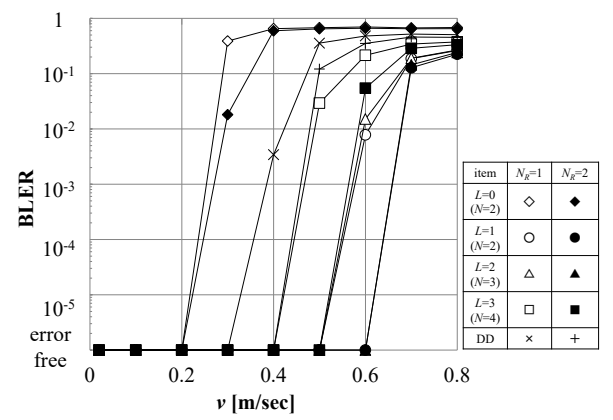

図 $5 \quad v$ 変化時の BLER 特性 (DMSC2)

Fig. 5 BLER performance as a fuction of $v$ (DMSC2)

本節では実験水槽における 2 重選択性を模擬した環 境における実験性能評価について述べる。図 2 に実験 について概要図を示す。実験水槽において，受信トラ ンスデューサ Rx1，Rx2 は互いの間隔を $1.0 \mathrm{~m}$ とし，水 深 $1.0 \mathrm{~m}$ で固定する。送信トランスデューサ Tx は $2 \supset$ の受信トランスデューサの中間の直下に設置する。ま た，送信トランスデューサは受信トランスデューサか ら $0.25 〜 1.25 \mathrm{~m}$ の距離を往復する。なお本実験に用い

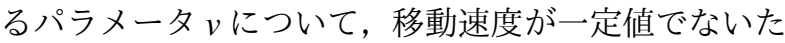
め, 移動距離と経過時間から求まる平均速度 $v$ を用い て近似する。このように送信トランスデューサの移動 により，時間選択性を模擬する。次に，周波数選択性 について, 実験水槽内には吸音材が設置されているた め, 底面, 壁面からの反射は到来しない。反射波が確 認できる位置に反射板を設置することで，水面からの 反射と合わせ，厳しい周波数選択性を模擬する。著者 らは文献 [12] において，反射板を設置していない場 合における性能評価を実施している。本実験では反射 板を設置することで，文献 [12] にて実施した実験と は異なる環境となっている。本実験では受信トランス デューサが 1 本, 2 本の場合の結果を比較することで, 受信ダイバーシチの効果について検証する。困 3 に,

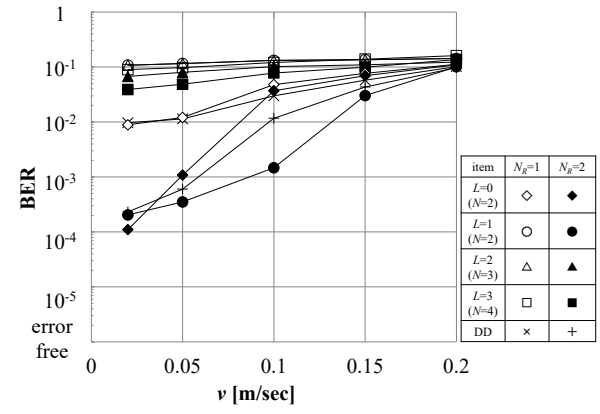

図 $6 v$ 変化時の BER 特性 (DMSC4)

Fig. 6 BER performance as a fuction of $v$ (DMSC4)

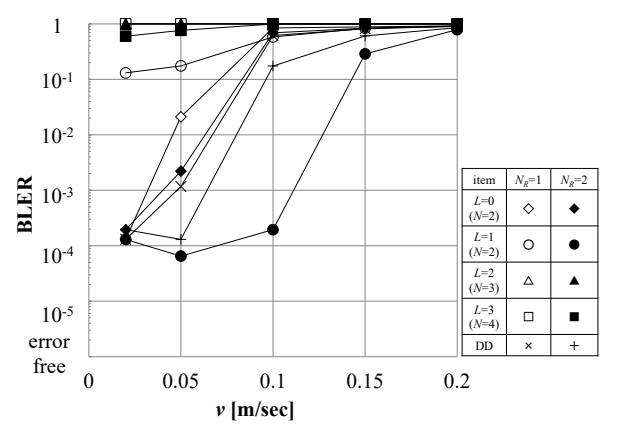

図 $7 v$ 変化時の BLER 特性 (DMSC4)

Fig. 7 BLER performance as a fuction of $v$ (DMSC4)

$\mathrm{Tx}$ の深度 $2.25 \mathrm{~m}$ における Tx-Rx1 間の CIR 特性を示 す。CIR 特性について, 文献 [17], [18] 記載の変形 M 系列によるチャネルサウンダを用いて算出する。図 3 より, 直接波が到達してから約 $0.6 \mathrm{msec}$ 後に電力が最 も大きい遅延波が到達していることが確認できる。

\section{2 実験性能評価結果}

図 4 に伝送方式が DMSC2 時の，vをパラメータと した場合の BER 特性を, 図 5 に BLER 特性を示す。 次に，図 6 に伝送方式が DMSC4 時の $v$ をパラメータ とした場合の BER 特性を, 図 7 に BLER 特性を示す。 ここで, $L$ は伝送路予測次数, $N$ は受信信号の観測シ ンボル数, $N_{R}$ は受信トランスデューサ数を示す。加 えて, 比較のために, 復調方式として DD を適応した 場合の特性を付記する。図 6, 図 7 について, $L=3$ の場合のみ PSP-MLSE ではなく, PSP-DFSE で復調 した場合の結果を記載する。16PSK， $L=3$ の条件で は, PSP-MLSE を採用した場合, VA の状態数は 4096 状態と非常に大きい值となる。そのため, $\Delta V=1$ の PSP-DFSE を採用し状態数を削減する。

図 4, 図 5, 図6, 図 7 より, 検討するUWACモデム 
の耐 2 重選択性が確認できる。図 4, 図 6 より $N_{R}=1$, $N_{R}=2$ それぞれの結果を比較した時, 受信ダイバーシ チの効果が確認できる。本論文では BLER 特性につい て, 5.2 記載の想定する通信システムより，10 $10^{-3}$ をー ゲットとして考える。例えば，画像データ通信を想定 した時, BLER が 10 $0^{-3}$ の場合では 1000 枚中 999 枚は 正確なデータが伝送され，通信システムによる運用が 可能であると考えられるため, 良好な性能と言える。 図より，DMSC2，DMSC4，両伝送方式において 1 次 伝送路予測を用いた復調方式が最も優れた追随性を持 つことが確認できる。その理由は, 今回の伝送路では, 周波数選択性による信号歪みと送信トランスデューサ の移動による位相回転のみが影響を及ぼすため，2 次 以上に予測次数を拡大したことによる追随特性の改 善効果より, ゆらぎ量の増大が大きいためと考えられ る。図 4, 図 5 より, 伝送方式が DMSC2 の場合, DD は $0.4 \mathrm{~m} / \mathrm{sec}$, 検討方式は $0.6 \mathrm{~m} / \mathrm{sec}$ まで良好な性能を示 す。BLER 特性より，vと表 2, また図 3 の条件におい て, 対応可能な $f_{D} \tau_{D}$ が算出できる。つまり, 伝送方 式が DMSC2 の場合, DD は $f_{D} \tau_{D}=0.48 \%$, 検討方式 は $f_{D} \tau_{D}=0.72 \%$ の環境に対応できる。図 6 , 図 7 よ り，伝送方式が DMSC4 の場合，DD は $0.05 \mathrm{~m} / \mathrm{sec}$ ，検 討方式は $0.1 \mathrm{~m} / \mathrm{sec}$ まで良好な性能を示す。DMSC2 の 場合と同様に計算を行うと，伝送方式が DMSC4 の場 合, $\mathrm{DD}$ は $f_{D} \tau_{D}=0.06 \%$, 検討方式は $f_{D} \tau_{D}=0.11 \%$ の環境に対応できる。両伝送方式において検討方式は DD と比較して, 耐 2 重選択性の改善が確認できる。

\section{7. 海洋浅瀬環境における実験}

海洋浅瀬環境における実験性能評価として, 海洋 バージ内での試験と海洋バージ・栈橋間試験の $2 つ 0$ 試験を実施する。本章では，2 重選択性の中でも周波 数選択性に重点をおいて評価を実施する。その結果， 周波数選択性に対しては, 伝送路平均が有効であるこ とを明らかにする。

\section{1 海洋バージにおける実験}

図 8 に海洋バージにおける実験の概要図を示す。こ こで, 海洋バージ周辺の水深は約 $30 \mathrm{~m}$ である。本環境 は, 比較的周波数選択性が緩やかな環境条件として設 定している。また, 条件 (1) と条件 (2) の 2 条件は, 水 深, 水平距離を変化させることにより, 周波数選択性 がどのように変化するかを確認するために設定してい る。図 9 に図 8 における条件 (1) の CIR 特性を示す。
ここで, 図 9 の $4 \mathrm{msec}$ あたりに発生する小さなパス は, 海面による反射と考えらえる。また, 図 10 に図 8 における条件 (2) の CIR 特性を示す。図 9, 図 10 よ り, Tx の深度 $25 \mathrm{~m}$ の場合は $\mathrm{Tx}$ の深度 $5 \mathrm{~m}$ の場合と比 較して, マルチパス成分が少ないことが確認できる。

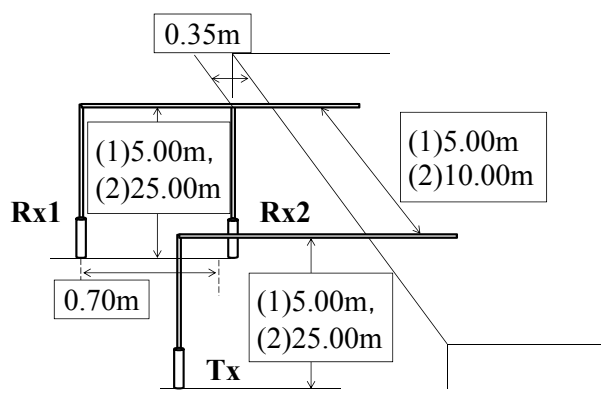

図 8 海洋バージにおける実験の概要図

Fig. 8 Configuration of the experiment in shallow-sea environment

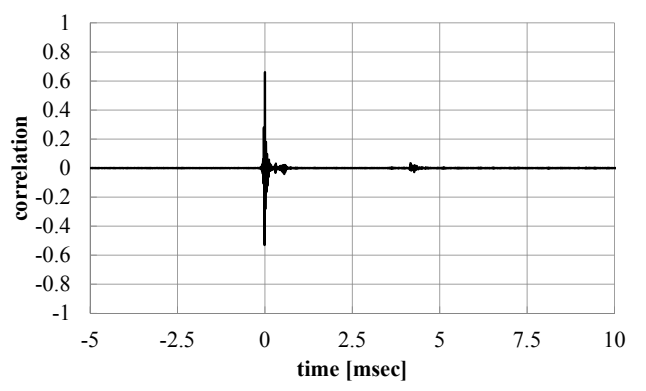

図 9 海洋バージ試験の CIR 特性（Tx の深度 $5 \mathrm{~m}$ )

Fig. 9 CIR in shallow-sea environment (depth of Tx $5 \mathrm{~m})$

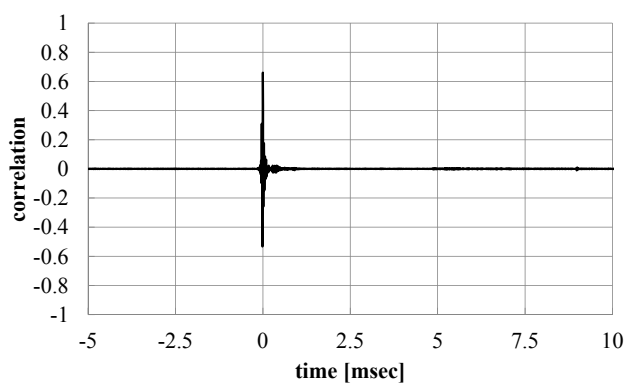

図 10 海洋バージ試験の CIR 特性（Tx の深度 25m） Fig. 10 CIR in shallow-sea environment (depth of Tx $25 \mathrm{~m})$

表 3 に(1)の条件時における各モデムの BER/BLER 特性を示す。表 4 に(2) の条件時における各モデムの $\mathrm{BER} / \mathrm{BLER}$ 特性を示す。 
表 3 BER/BLER 特性 (条件 (1) 時)

Table 3 BER/BLER performance (condition (1) in Fig.

8)

\begin{tabular}{|c|c|c|c|c|c|c|}
\hline 伝送方式 & 復調方式 & $L$ & $N$ & $N_{R}$ & BER & BLER \\
\hline DMSC 2 & DD & 0 & 1 & 2 & $2.5 \times 10^{-7}$ & error free \\
\hline & PSP-MDD & 0 & 2 & 2 & $9.9 \times 10^{-7}$ & error free \\
\hline & PSP-MDD & 1 & 2 & 2 & $9.9 \times 10^{-7}$ & error free \\
\hline DMSC4 & DD & 0 & 1 & 2 & $5.7 \times 10^{-3}$ & $7.9 \times 10^{-4}$ \\
\hline & PSP-MDD & 0 & 2 & 2 & $5.0 \times 10^{-3}$ & $2.6 \times 10^{-4}$ \\
\hline & PSP-MDD & 1 & 2 & 2 & $1.6 \times 10^{-2}$ & $1.0 \times 10^{-1}$ \\
\hline
\end{tabular}

表 4 BER/BLER 特性 (条件 (2) 時)

Table 4 BER/BLER performance (condition (2) in Fig. 8)

\begin{tabular}{|c|c|c|c|c|c|c|}
\hline 伝送方式 & 復調方式 & $L$ & $N$ & $N_{R}$ & BER & BLER \\
\hline DMSC2 & DD & 0 & 1 & 2 & error free & error free \\
\hline & PSP-MDD & 0 & 2 & 2 & $7.4 \times 10^{-7}$ & error free \\
\hline & PSP-MDD & 1 & 2 & 2 & error free & error free \\
\hline DMSC4 & DD & 0 & 1 & 2 & $6.2 \times 10^{-4}$ & $2.0 \times 10^{-4}$ \\
\hline & PSP-MDD & 0 & 2 & 2 & $2.9 \times 10^{-4}$ & $2.0 \times 10^{-4}$ \\
\hline & PSP-MDD & 1 & 2 & 2 & $5.3 \times 10^{-3}$ & $2.1 \times 10^{-3}$ \\
\hline
\end{tabular}

海洋バージにおける実験により以下のことが確認で きる。

- 伝送方式が DMSC2 の場合，(1), (2) 両条件にお いて各復調方式は良好な性能を示す

- 伝送方式が DMSC4 の場合，(1), (2) 両条件にお いて PSP-MDD $(L=1)$ は他の復調方式と比較し て性能が劣化している。これは伝送路予測によ る雑音強調が影響していると考えられる

- 伝送方式が DMSC4 の場合，(1), (2) 両条件に おいて PSP-MDD $(L=0), \mathrm{DD}$ は良好な性能を 示す

7.2 海洋バージ・栈橋間試験

図 11 に海洋バージ・栈橋間における実験の概要図を, 図 12 に実験の俯瞰図を示す。ここで，栈橋にて受信卜 ランスデューサは，コンクリート岸壁から約 $2 \mathrm{~m}$ 海洋 バージ側に設置している。本環境は, 比較的周波数選 択性が厳しい環境条件として設定している。また，図 13 に海洋バージ・栈橋間の CIR 特性を示す。表 5 に海 洋バージ・栈橋間試験における各モデムの BER/BLER 特性を示す。表 5 により以下のことが確認できる。

- PSP-MDD $(L=1)$ を用いた場合，周波数選択性 の影響により性能が劣化する

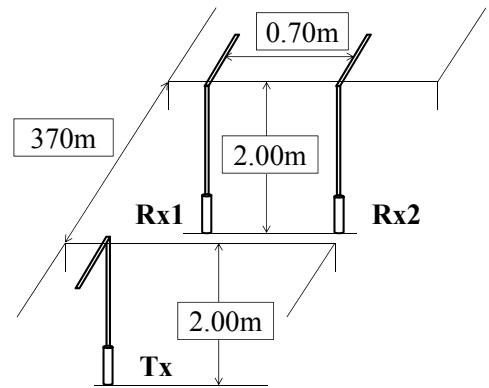

図 11 海洋バージ・栈橋間における実験の概要困

Fig. 11 Configuration of the $370 \mathrm{~m}$ experiment

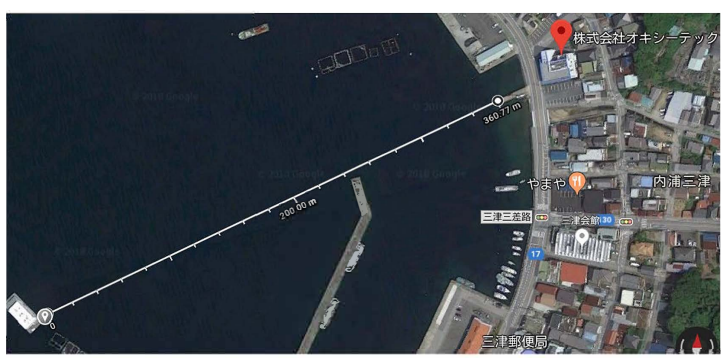

図 12 海洋バージ・栈橋間における実験の俯瞰図 Fig. 12 Aerial view of the $370 \mathrm{~m}$ experimental environment

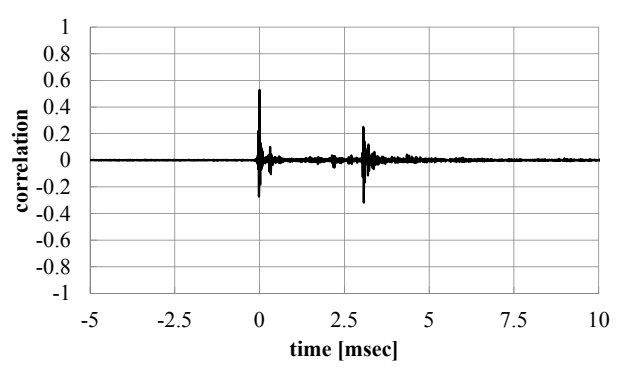

図 13 海洋バージ・栈橋間の CIR 特性

Fig. 13 CIR in the $370 \mathrm{~m}$ experimental environment

表 5 BER/BLER 特性 (海洋バージ・栈橋間試験) Table 5 BER/BLER performance of the $370 \mathrm{~m}$ expri-

ment
\begin{tabular}{|c|c|c|c|c|c|c|}
\hline 伝送方式 & 復調方式 & $L$ & $N$ & $N_{R}$ & BER & BLER \\
\hline DMSC 2 & DD & 0 & 1 & 2 & $7.0 \times 10^{-3}$ & error free \\
\hline & PSP-MDD & 0 & 2 & 2 & $4.9 \times 10^{-3}$ & error free \\
\hline & PSP-MDD & 1 & 2 & 2 & $2.2 \times 10^{-2}$ & $3.6 \times 10^{-1}$ \\
\hline DMSC4 & DD & 0 & 1 & 2 & $9.6 \times 10^{-2}$ & 1.0 \\
\hline & PSP-MDD & 0 & 2 & 2 & $9.6 \times 10^{-2}$ & 1.0 \\
\hline & PSP-MDD & 1 & 2 & 2 & $1.7 \times 10^{-1}$ & 1.0 \\
\hline
\end{tabular}


- 伝送方式が DMSC2 の場合では, PSP-MDD $(L=$ 0), DD は良好な性能を示す

表 3, 表 4, 表 5 に表される結果より，伝送方式が DMSC2 の場合は $370 \mathrm{~m}$ の通信, DMSC4 の場合は $10 \mathrm{~m}$ 程度の通信が可能であることが確認できる。また，厳 しい周波数選択性が影響を与える準固定環境において， PSP-MDD $(L=0)$ が有効であると考えられる。

\section{8. むすび}

本論文では，厳しい 2 重選択性伝搬環境に有効な伝 送路予測 PSP-MDD を用いた差動MSC 伝送方式による 通信方式を提案した。また提案手法を用いた UWAC モ デムについて，2つの実験性能評価試験を行い，UWAC モデムが UWAC 環境に対して有効であることを確認 した。まず，実験水槽試験から，1 次伝送路予測を用 いたPSP-MDDについて優れた耐 2 重選択性，特に， 耐時間選択性を確認した。次に, 海洋浅瀬環境試験か らQPSK を用いた検討方式では距離 370m，16PSK を 用いた検討方式では距離 $10 \mathrm{~m}$ 程度の通信が可能であ ることを確認した。また海洋浅瀬環境において準固定 環境では PSP-MDD $(L=0)$ が最も良好な性能を有す ることを確認した。以上より，2 重選択性伝搬環境に おいて, 時間選択性を重視する場合は $L=1$, 周波数 選択性を重視する場合は $L=0$ の方が有効である。そ れゆえ, 受信側で 2 重選択性の状況に合わせて， $L$ を 選択する復調方式が有効となる。

本論文で検討した通信モデムの実験性能評価結果に ついて, 以下の課題が残留している。

・検討した UWAC モデルは表 1 で示した $f_{D} \tau_{D}$ を 達成するために, 更なる耐 2 重選択性の改善が 必要である。

・通信に使用している信号帯と, トランスデュー サの共振周波数との整合性について，十分に検 討していない。

・海洋浅瀬環境における試験について, 移動環境 試験を実施していない。

・並列ブラインド復調方式 [19] のような伝搬環境 に合わせて， $L$ を選択する手法について検討し ていない。

上記について, 筆者らの今後の課題として検討する予 定である。

謝辞 本研究は JSPS 科研費 $19 K 04382$ の助成を受けたもの
である。加えて, 本研究実施に関してご協力頂いた株式会 社オキシーテックの関係各位に深く感謝致します。

\section{参考文献}

[1] P. Kumar, V.K. Trivedi and P. Kumar: Recent trends in multicarrier underwater acoustic communications, Underwater Technology (UT), IEEE, Feb. 2015.

[2] H. Ochi, Y. Watanabe and T. Simura: Basic study of underwater acoustic communication using 32-quadrature amplitude modulation, Japanese Journal of Applied Physics, Vol. 44, No. 6B, pp. 4689-4693, June 2005.

[3] A.C. Singer, J.K. Nelson and S.S. Kozat: Signal processing for underwater acoustic communications, IEEE Commun. Mag., Vol. 47, pp. 90-96, Jan. 2009.

[4] S. Yoshizawa, H. Tanimoto and T. Saito: SC-FDE vs OFDM: Performance comparison in shallow-sea underwater acoustic communication, Proc. ISPACS2016, IEEE, Oct. 2016.

[5] C. Li, K. Song and L. Yang: Low computational complexity design over sparse channel estimator in underwater acoustic OFDM communication system, IET Commun., Vol. 11, pp. 1143-1151, May 2017.

[6] J. Tao, L. An and Y.R. Zheng: Enhanced adaptive equalization for MIMO underwater acoustic communications, OCEANS, IEEE, Sep. 2017.

[7] 宮崎律子, 久保博嗣: 高速フェージングのためのマルチキャリ ア高次予測判定帰還遅延検波, 信学技報, Vol. RCS2014-35, pp. 19-24, June 2014.

[8] J.G. Proakis and M. Salehi: Digital Communications, Fifthedition New York : McGraw-Hill, 2008

[9] D. Divsalar and M.K. Simon: Multiple-symbol differential detection of MPSK, IEEE Trans. Commun., Vol. COM-38, 3, pp. 300-308, Mar. 1990.

[10] H. Kubo, A. Okazaki, K. Tanada, B. Penther and K. Murakami: A multiple-symbol differential detection based on channel prediction for fast time-varying fading, IEICE Trans. Commun., Vol. E88-B, No. 8, pp. 3393-3400, Aug. 2005.

[11] 吉井綸太朗, 竹村真志, 高橋拓也, 久保博嗣: 水中音響通信のため の $64 \mathrm{kbps}$ 差動マルチキャリア伝送方式と Per-Survivor Processing による予測形多重遅延検波, 信学技報, Vol. RCS2018-59, pp. 143-148, June 2018.

[12] 竹村真志, 塚本圭哉, 吉井綸太朗, 高橋拓也, 久保博嗣: マル チキャリア伝送路予測 Per-Survivor Processing 多重遅延検波 のためのオフライン水中音響ソフトウェアモデム, Journal of Signal Processing, Vol. 23, No. 3, pp. 115-126, May 2019.

[13] 久保博嗣: 高速時変伝送路に適した差動時空符号化とその無 線通信システムへの応用, 信学技報, Vol. RCS2013-193, pp. 87-91, Nov. 2013.

[14] 久保博嗣: 厳しい 2 重選択性伝搬路に適した無線伝送方式, 信 学技法, Vol. CQ2018-48, pp. 13-18, Aug. 2018.

[15] 久保博嗣, 森俊樹, 村山陽寛, 山岸拓真, 湯本菜々瀬: 高速時変 伝送路のための伝送路予測形差動時空符号化の比較, 信学技 報, Vol. RCS2017-330, pp. 75-80, Mar. 2018.

[16] A. Duel-Hallen and C. Heegard: Delayed decision-feedback sequence estimation, IEEE Trans. Commun., Vol. 37, No. 5, pp. 428-436, May 1989. 
[17] 村山陽寛, 森田宗一郎, 相澤大, 上田俊一, 市川貴英, 久保博嗣: 市販の音響電子機器を用いた水中音響通信用チャネルサウ ンダとそのフィールド評価結果, Journal of Signal Processing, Vol. 21, No. 3, pp. 97-107, May 2017.

[18］森田宗一郎, 村山陽寛, 湯本菜々瀬, 中務光基, 竹村真志, 久保 博嗣: 変形 $\mathrm{M}$ 系列による 2 重選択性音響伝送路用チャネル サウンダ, Jornal of Signal Processing, Vol.23, No. 1, pp. 23-34, Jan. 2019.

[19] H. Kubo, A. Okazaki, K. Tanada, B. Penther and M. Miyake: A parallel blind demodulator in the presence of intersymbol interference, IEEE ICC2001, Vol. 8, pp. 2520-2524, June 2001.

[20] F. Adachi and M. Sawahashi: Decision feedback multiplesymbol differential detection for M-ary DPSK, IEE Electronics Letters, Vol. 29, No. 15, pp. 1385-1387, July 1993.

[21] N. Seshadri: Joint data and channel estimation using blind trellis search techniques, IEEE Trans. Commun., Vol. 42, Nos. 2/3/4, pp. 1000-1011, Feb./March/April 1994.

[22] H. Kubo, K. Murakami and T. Fujino: An adaptive maximumlikelihood sequence estimator for fast time-varying intersymbol interference channels, IEEE Trans. Commun., Vol. 42, Nos. 2/3/4, pp. 1872-1880, Feb./March/April 1994.

[23] R. Raheli, A. Polydoros and C.-K. Tzou: Per-survivor processing: A general approach to MLSE in uncertain environments, IEEE Trans. Commun., Vol. 43, Nos. 2/3/4, pp. 354-364, Feb./March/April 1995.

[24] 久保博嗣, 竹村真志, 塚本圭哉, 吉井綸太朗, 高橋拓也, 佐野 隆貴: 水中音響モデムの実験性能評価結果, 信学技報, Vol. RCS2018-306, pp. 133-138, Mar. 2019.

\section{付録 トランスデューサの特性}

本論文で実施した実験性能評価試験について，図 A.1 及び図 A.2 に，試験に用いた送信トランスデュー サ, 受信トランスデューサの振幅周波数特性, 指向特 性（水平・垂直方向）を示す。図 A.1 及び図 A.2 より, 所望の帯域，約 13〜43kHzに対して，送信トランス デューサ及び受信トランスデューサが比較的良好な性 能を持つことが確認できる。

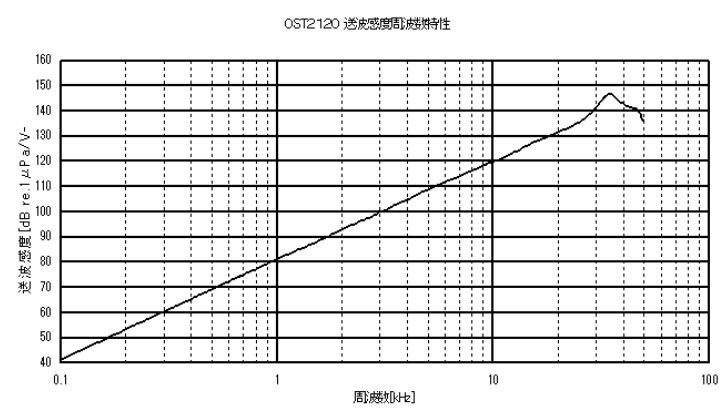

図 A.1(a) 送信トランスデューサ振幅周波数特性

Fig. A.1(a) Amplitude frequency characteristics of transmit transducer
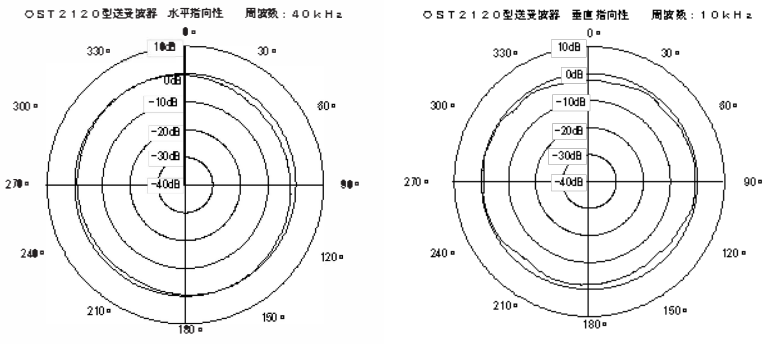

図 A.1(b) 送信トランスデューサ指向特性

Fig. A.1(b) Directivity characteristics of transmit transducer

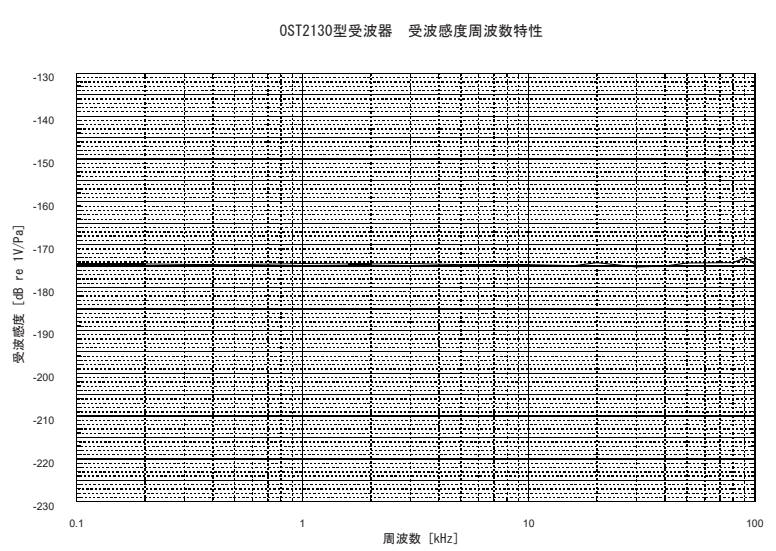

図 A.2(a) 受信トランスデューサ振幅周波数特性 Fig. A.2(a) Amplitude frequency characteristics of receive transducer

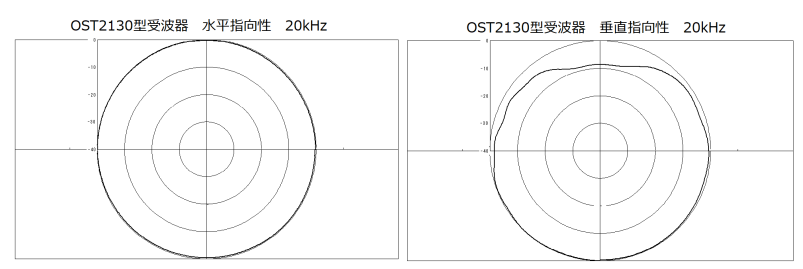

図 A.2(b) 受信トランスデューサ指向特性 Fig. A.2(b) Directivity characteristics of receive transducer 


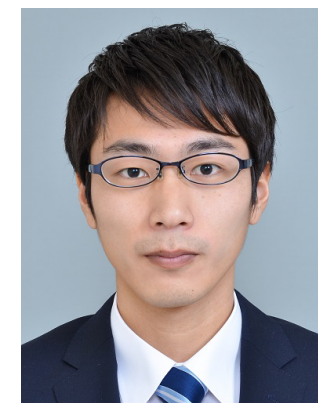

吉井 綸太朗 2018 年立命館大学理 工学部電子情報工学科卒業。現在, 立 命館大学大学院理工研究科電子システ 厶専攻在学中。ディジタル無線通信方 式の研究に従事。

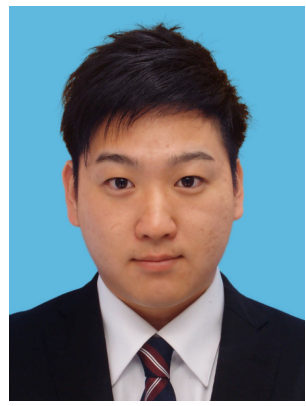

塚本 圭哉 2018 年立命館大学理工 学部電子情報工学科卒業。現在, 立命 館大学大学院理工研究科電子システム 専攻在学中。ディジタル無線通信方式 の研究に従事。

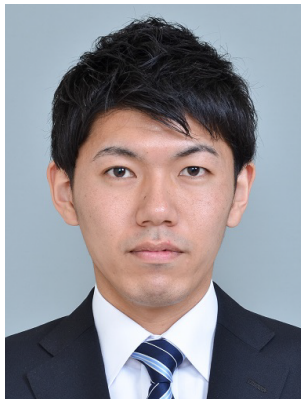

高橋 拓也 2018 年立命館大学理工 学部電子情報工学科卒業。現在, 立命 館大学大学院理工研究科電子システム 専攻在学中。ディジタル無線通信方式 の研究に従事。

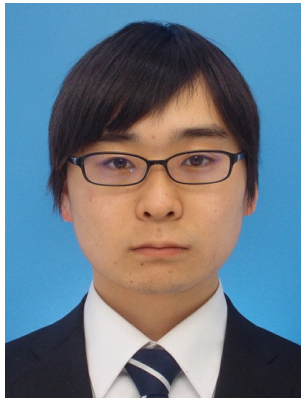

竹村 真志 2017 年立命館大学理工 学部電子情報工学科卒業。2019 年立 命館大学大学院理工研究科電子システ 厶専攻修了。在学中はディジタル無線 通信方式の研究に従事。

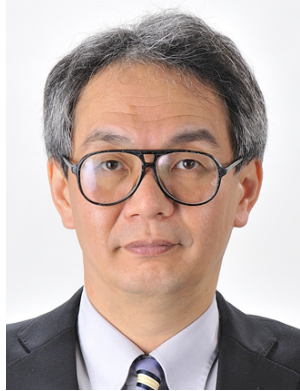

久保博嗣 1984 年大阪大学工学部 通信工学科卒業。1986 年大阪大学大 学院工学研究科修士課程修了。同年三 菱電機 (株) 入社。同社情報技術総合研 究所無線通信技術部部長を経て, 2012 年から立命館大学理工学部電子情報工 学科教授。ディジタル無線通信方式の 研究開発に従事。平成 6 年度電子情報 通信学会学術奨励賞, 平成 21 年度第 20 回電波功績賞電波産業会長賞, 平 成 22 年度科学技術分野の文部科学大 臣表彰科学技術賞受賞。工博。電子情 報通信学会シニア会員，IEEE 会員，RISP 会員。

（2019 年 8 月 8 日受付 ; 2019 年 12 月 26 日再受付） 